\title{
Online contract training: Applying organization theory to reconcile competing missions within community colleges
}

Rajashi Ghosh

University of Louisville

Rod P. Githens

University of the Pacific, rgithens@pacific.edu

Follow this and additional works at: https://scholarlycommons.pacific.edu/ed-facpres

Part of the Education Commons

\section{Recommended Citation}

Ghosh, Rajashi and Githens, Rod P., "Online contract training: Applying organization theory to reconcile competing missions within community colleges" (2010). Benerd School of Education Faculty Presentations. 267.

https://scholarlycommons.pacific.edu/ed-facpres/267 
Running head: ONLINE CONTRACT TRAINING AND COMMUNITY COLLEGES

Online Contract Training: Applying Organization Theory to Reconcile Competing

Missions within Community Colleges

Rajashi Ghosh

Drexel University

Rod P. Githens

University of Louisville

Copyright (C) 2010 Rajashi Ghosh \& Rod P. Githens 


\begin{abstract}
Community colleges in the United States have become major providers of training services to American employers, particularly through offering workforce development training to local employers. The addition of workforce development services to community colleges is a fairly recent phenomenon. Some see workforce development efforts as diluting the historic mission of providing affordable and accessible opportunities for students to transfer to four-year institutions. The addition of online training has created additional stressors, due to increases in costs, opportunities for outsourcing, and increased opportunity for serving those outside of the local community. Using an organizational theory framework, this conceptual paper addresses the competing emphases in the community college mission and attempts to understand how various types of institutions overcome internal and external barriers in introducing online workforce development through organizational change initiatives.

Keywords: Online Workforce Development, Contract training, Organizational Change.
\end{abstract}




\section{Online Contract Training: Applying Organization Theory to Reconcile Competing Missions within Community Colleges}

Community colleges are major providers of training services in the U.S. As part of their workforce and economic development mission, they offer non-credit courses in a wide range of topics, such as basic software skills, management development, customer service skills, total quality management, and safety skills. However, they also offer highly specialized training in technical fields such as healthcare, manufacturing, and software development. Although participants often enroll directly in such courses, community colleges commonly enter into contracts to provide direct training for employers and other organizations like labor unions and business groups.

Contract training is a form of workforce development that is arranged with an organization for the development of a particular group of people, usually an organization's employees. Either the content or the delivery modes are typically customized in some way to meet a particular employer's needs (Grubb \& Stern, 1989). In some cases, entire courses or programs are developed to meet the needs of the client (Bragg \& Jacobs, 1993). Such training could involve on-campus delivery, delivery at the employer's site, or online delivery (Dougherty \& Bakia, 2000). Contract training is typically non-credit bearing for students. Non-credit programs often result from formal and informal partnerships with employers, labor unions, community agencies, and others to promote a more expansive workforce development mission (Orr, 2001). The result is a widespread perception of the community college as a unique type of institution with the deeply engrained goal of responding to community needs. According to a national study, most state legislators concluded that community colleges are highly responsive to workforce training needs, when compared with other forms of higher education (Ruppert, 2001). 
In the last 10-15 years, community colleges have begun offering online courses as part of their workforce development efforts. Community colleges are now the leading providers of credit-bearing online courses in the U.S. (Allen \& Seaman, 2003). Community colleges that responded to the Instructional Technology Council's annual survey (2008) indicated an 18\% increase in online enrollment over the previous year. Additionally, $67 \%$ of survey respondents indicated that they offer non-credit online education courses, up $6 \%$ from the previous year. Despite the large number of online courses, $70 \%$ of survey respondents indicated that their college is not keeping pace with demand for online courses. Blended courses, which use a hybrid of face-to-face and online deliveries, are also quite common in contract training.

Despite the growth and opportunities for providing online contract training, offering such services presents further challenges to the multifaceted mission of community colleges. The goals of providing traditional academic transfer courses, credit-bearing occupational courses, continuing education opportunities for personal growth, industry contract training, and developmental education (i.e., remedial and basic skills courses) have sometimes been seen as competing and causing a dilution of the overall effectiveness of community colleges in an era of declining funding (Cohen \& Brawer, 2003; Jacobs \& Dougherty, 2006; Kasper, 2003). In particular, the tension between general education/transfer and occupational education has been a consistent point of contention within community colleges (Jacobs \& Dougherty, 2006). In the last 20 years, the growth of non-credit contract training has further expanded the occupational arm of community colleges to a more explicit connection with workforce and economic development. The more recent emergence of online contract training provides additional points of contention and potential dilution of institutional mission due to the increased demands for technology resources, increased potential for outsourcing, and opportunity to serve employers outside the community in which an institution is located. 
In view of these issues, this paper explores the potential conflicts of contract training, especially online contract training with institutional mission of community colleges, and discusses the opportunity for enhancing the reach of institutional engagement in community colleges by reconciling competing interests and institutional barriers through organizational change initiatives. The organizational changes discussed for reconciliation of competing interests and barriers are guided by the Astley and Van de Ven (1983) theoretical framework from the organizational theory literature. This culmination of the paper's arguments occurs after the groundwork has been laid for understanding the problems and potentials of online contract training.

\section{Connection Between Contract Training and Institutional Mission}

From their inception in the early 1900s, community colleges have undergone a paradigm shift in their mission (Bailey \& Averianova, 1998). Primarily, there are two sometimes-opposing views regarding the purpose of community colleges (Jacobs \& Dougherty, 2006). The primary tension lies between the academic transfer and occupational functions of a community college. According to one school of thought, the mission of community colleges is to provide equal access to higher education for people who face economic and social barriers in the community (Eaton, 1994; Cohen \& Brawer, 1996). This goal has primarily manifested through the community colleges' focus on preparing students to transfer to four-year colleges and universities. However, since the 1960s, community colleges have begun expanding their focus beyond the original goal of providing transfer education. Institutions have increasingly invested in occupational education designed to prepare students explicitly for employment. Critics of occupational education argue that by advocating a narrow focus on employment, community colleges limit their students' expectations and aspirations to the realities of the labor market (Bailey \& Averianova, 1998). Despite such criticisms, the continued interest of community 
colleges in occupational education has allowed them to significantly contribute to the economic development of their communities (Katsinas, 1994). As occupational programs provide more direct linkages with workforce and economic development, community colleges are uniquely connected with their communities by providing facilities for community use, displaying agility in responding quickly to employer needs, and providing inexpensive educational opportunities.

According to a national studies of community and technical colleges, $93 \%$ offered academic or transfer degrees (United States Government Accountability Office, 2004) and over 96\% offered occupational degree programs (Levesque, et al., 2008; United States Government Accountability Office, 2004). These findings illustrate that most community colleges have shifted from the original transfer mission to a dual mission focusing on both academic transfer and workforce development. Although this interest in workforce and economic development has provided financial benefits to both community colleges and communities, an ongoing debate exists about whether this dual commitment to academic education and occupational education is sustainable in the long term.

This article is concerned with a particular type of occupational education that has helped community colleges to build partnerships with businesses. In the last four decades, community colleges have gradually broadened their role in economic development by providing customized training under contracts to business organizations for the primary purpose of improving generic and firm-specific job skills of their future and current employees (Dougherty \& Bakia, 2000). Community colleges in the South became involved in offering these programs in the late 1960s as a part of statewide economic development efforts (Bragg \& Jacobs, 1993). According to Grubb and Stern (1989), contract or customized training is defined as "relatively firm-specific skill training for individual firms, and therefore, a form of training which is more specifically responsive to a firm's requirements than are general vocational programs" (p. 31). 
Contract training spread to other regions beginning in the 1980 s, as a result of the recession. Unlike traditional occupational education, contract training involves an employer or organization as the primary client instead of an individual student (Dougherty \& Bakia, 2000). As noted by Dougherty and Bakia (2000), the extent of customization in contract training might vary from content adaptation (e.g. the content is adapted to or created for the needs of a particular client) to schedule, structure, and location adaptations (e.g., nonstandard schedules over weekends at the client's location) for a particular course. Although contract training is often equated with training in firm-specific skills, Lynch, Palmer, and Grubb (1991) estimate that about $12 \%$ of all contract courses offered by community colleges are for training in generic skills such as basic skills in reading, writing, and arithmetic and advanced skills in "lean manufacturing" and "just in time” production (Dougherty \& Bakia, 2000). Such skills are typically transferable across employers. Thus, for the purposes of contract training in such generic skills, regular courses offered by community colleges are used with minimal content adaptation or customization and serve a broader societal purpose beyond the needs of a particular employer.

Irrespective of the extent of customization, the practice of contract training is quite pervasive among community colleges (Lynch \& Black, 1998; Lynch et al., 1991). A national study found that $79 \%$ of community colleges offer this type of contact training (United States Government Accountability Office, 2004). These contractual liaisons with business concerns have further challenged community colleges' original mission of commitment to equity and access for all types of students (Bailey \& Averianova, 1998). The challenges have mainly manifested through financial limitations in absence of outside funding allotted for non-credit workforce education. According to Dougherty (2003), state funding is sometimes connected to providing training for certain favored sectors of the economy thought to bring higher economic 
returns. Larger business establishments in healthcare and manufacturing are heavy recipients of contract training, whereas smaller establishments and businesses in wholesale and retail trade have fewer opportunities for receiving government subsidies, which can result in them not being able to utilize the services provided by community colleges. Dougherty's research shows that contract training directors specifically target large employers in certain sectors of the economy because they are "lower hanging fruit."

\section{Challenges to Offering Online Contract Training}

Online contract training requires community colleges to employ a vast array of technological innovations in online instruction and administrative support (Foster, 2004). Although some community colleges are successfully developing technical infrastructures to support the latest technologies available for e-learning, other colleges struggle with fiscal constraints and are losing their competitive edge to alternative providers of online workforce development (Dougherty, 2003). Alternative providers such as private consultants, equipment vendors, trade and professional associations, for-profit career colleges, and labor/management joint apprenticeship programs are offering competitive online contract training modules to business organizations. In high-tech skills programs, online simulations or equipment for handson training requires substantial investments. These alternate providers are challenging the salience of community colleges' role in online contract training primarily because they can afford substantial investments to build a technical infrastructure and employ staff who are trained in specialized up-to-date technical knowledge.

Although at least $75 \%$ of institutions receive state funds to subsidize contract training (United States Government Accountability Office, 2004), not all institutions attain outside assistance, which helps in buying the latest technology and training their faculty and staff on new technology, techniques, and software (Dougherty, 2003). According to Van Noy and Jacobs 
(2009), 22 states in the U.S. do not have any form of state funding specifically for non-credit workforce development in community colleges. Institutions in those states must fund contract training from training fees and other types of workforce training grants (Boswell, 2000). Since government aid tends to favor certain industries like manufacturing, community colleges have little or no state funding for training in industries not favored by government subsidies. Thus, many community colleges are left with the option of increasing the cost of non-credit and contract courses in order to fund the technical infrastructure needed for online workforce development. As most of the states lack any statutory limit on what community colleges can charge for non-credit workforce education, they often charge what the market bears for noncredit courses (Van Noy \& Jacobs, 2009). Hence, organizations that belong to industries which do not receive state funding for online workforce development end up paying more for training modules than their counterparts belonging to the industries receiving state funding. The cost issue is especially important when considering training for fledgling or struggling companies and non-profit organizations. Some community colleges opt to outsource non-credit, contract online workforce development in order to address some of these cost issues (Bailey, Jacobs, \& Jenkins, 2004).

Outsourcing of instruction for online contract training at community colleges is a growing but still limited practice (Bailey, Jacobs, \& Jenkins, 2004). Community colleges can use their competitors' resources by contracting with them to provide online training. Such arrangements exist between community colleges and private consultants, equipment vendors, trade and professional associations, and large e-learning companies. Although the vendors could seek clients without community colleges, they engage in such collaboration to get ready access to a large pool of potential customers through the marketing efforts and name recognition of community colleges (Bailey, Jacobs, \& Jenkins, 2004). Outsourcing instruction for online 
contract training allows community colleges to offer a broader set of updated training programs, a wider range of delivery modes, and services that would be difficult or expensive for them to obtain individually. The extent of outsourcing can vary according to the need of the community college. An investigation of 11 community colleges suggests that the colleges contract out instruction when they need instructors with specialized knowledge or when they need an updated technical infrastructure (Bailey, Jacobs, \& Jenkins, 2004). Two popular vendors for non-credit courses are Ed2go and Gatlin Education Services. Ed2go offers instructor-facilitated courses with start and stop dates. The instructors are employees of Ed2go. Gatlin is known for selfstudy courses that allow self-paced study, with Gatlin managing the course design, development, and delivery. Outsourcing e-learning allows community colleges to access quality programs and a skilled instructor labor force that colleges might have difficulty developing through training their in-house faculty, particularly in highly-specialized niche areas (Foster, 2004).

However, the fundamental problem of outsourcing instruction for online contract training is the college's loss of control over the instructors and the pedagogical styles used in the online training modules (Bailey, Jacobs, \& Jenkins, 2004). Outsourcing can further isolate online contract training from the traditional for-credit academic education function of community colleges by not involving regular community college faculty (Lynch et al., 1991). Thus, such isolation results in contract education being not well integrated into other functions of community colleges and therefore, not being well integrated with the overall mission of community colleges.

Some colleges develop their own online non-credit courses, particularly in areas for which the college's contract training division is particularly well known (Githens, Wilson, Crawford, \& Sauer, 2009). Colleges offer programs like Six Sigma or Lean Manufacturing training to participants both inside and outside their own service areas. This broader offering of 
workforce development programs brings into question whether community colleges should be providing workforce development services for people and groups outside their service areas. Cox (2005) provides evidence of large, widespread enrollment in credit-bearing online courses by students outside of college districts. In defense of the practice, such offering could provide revenue generation that allows the institutions to provide additional services to their own communities. Niche specialization could also be justified since it allows individual colleges to become experts in specific subject areas rather than duplicating services across a larger geographical region. Such issues are part of a larger debate about the role of community colleges in serving populations beyond their communities (Cox, 2005).

\section{Using Organizational Theory to Reconcile Institutional Barriers and Various Missions through Organizational Change Initiatives}

This portion of the article attempts to reconcile the potentially problematic tensions within community colleges and discusses some organizational change initiatives that can help in reconciling competing interests and institutional barriers by juxtaposing different schools of thought in organizational theory, as presented by Astley and Van de Ven (1983). This lens helps us to understand how various organizational perspectives can help institutions overcome internal and external barriers in introducing online contract training. Particular emphasis is placed on developing solutions to the problem of competing resources within institutions, which results from the multifaceted demands addressed in community college missions.

Based on two analytical dimensions: (1) the level of organizational analysis, and (2) the relative importance of deterministic versus voluntaristic assumptions about human and organizational nature, Astley and Van de Ven (1983) provide four organizational perspectives that elicited the contrasting worldviews underlying the major debates in organizational theory. The four basic organizational perspectives are: (1) system-structural view, (2) strategic choice 
view, (3) natural selection view, and (4) collective action view. This paper uses these four dimensions to understand the various ways that community colleges can manage the challenges they face in providing effective online contract training. We recommend two of these organizational perspectives as frameworks for proposing organizational changes that can help community colleges to overcome those challenges and continue to serve their communities through effective workforce development.

\section{Reactive Role}

The systems-structural perspective on organizations is based on a deterministic orientation and focuses at the level of individual organizations. The deterministic orientation perceives an individual organization's actions to be reactive and mostly determined by structural constraints present in the context within which the organization exists. According to the systemsstructural view, organizations can at best react to external constraints that determine their survival or effectiveness. Thus, using the systems-structural perspective, the current challenges related to online contract training in community colleges would be seen as external constraints to which community colleges have to adapt in order to survive. Examples of such challenges include budgetary problems in updating the technical infrastructure, technology training for faculty, lack of state funds for online contract training, business firms being less willing to pay for training due to the economy, and the rise of new competitors providing online contract training at lower costs (Dougherty, 2003; Van Noy \& Jacobs, 2009). Such a perspective calls for reactive adaptation to the current challenges, such as increasing tuition and fees to pay for technical upgrades, reducing the number of online contract training services offered, devoting fewer resources to online noncredit workforce education, or scaling back on the offering of expensive occupational programs. We contend that community colleges taking such an approach would largely eschew a planned and systemic process of development for the purpose of 
improving organizational effectiveness and performance (Cummings \& Worley, 1997; Swanson

\& Holton III, 2009).

\section{Proactive Role}

In contrast to the systems-structural perspective, the strategic choice view focuses on a voluntaristic orientation at the level of individual organizations that involves proactive planning on behalf of the organization. The voluntaristic orientation views individual organizations as autonomous and self-directing agents that can manipulate external constraints in order to survive and be effective. Thus, according to the strategic choice perspective, community colleges have a choice to control the challenges and even modify them through innovative design of organizational structure and political negotiation of social interactions with the external environment. Examples of such proactive organizational changes in the context of community colleges include articulating noncredit online contract training with credit programs in order to facilitate better integration between the academic and occupational functions, pursuing an integrated organizational structure that allows appropriate movements between non-credit and credit programs in order to avoid the cost of duplication, providing customizable modular training, negotiating better pricing terms with employers, and utilizing entrepreneurial efforts to build funding streams required for providing state-of-the-art online contract training for workforce development (Moltz, 2009; Van Noy \& Jacobs, 2009). The convergence of creditbearing and non-credit courses is particularly helpful when an employer pays for non-credit training and the student decides to pursue a degree. Although this convergence presents organizational and accreditation challenges, it provides an opportunity for more fully integrated missions within institutions. With clearer connections between degree-granting programs and workforce development, the for-credit programs can become more integrated with the non-credit workforce development programs. Another noteworthy organizational change involves 
development of highly customizable modular training, in which participants take very small units of instruction, as they need them. At Kellogg Community College in Michigan, very small modules, worth fractions of a credit hour, are taken at their Regional Manufacturing Technology Center. These programs include reading, taking a written assessment, viewing videos, participating in online simulations, and completing hands-on assessments (Moltz, 2009). Such highly modularized programs can also be offered online or in hybrid formats, if colleges invest in developing the online content.

\section{Inactive Role}

A more macro perspective on organizations that contrasts with both the system-structural view and strategic choice view is the natural selection view that focuses on deterministic orientation at the level of multiple organizations. According to this perspective, groups or whole species of organizations (e.g., a whole industry) are at the mercy of the environment because they either fortuitously fit into a niche in that environment or are selected out and fail to develop a unique and competitive position for themselves in that environment. The perspective of the natural selection view is especially relevant for explaining the uneven distribution of online contract training by community colleges (Dougherty 2003). Larger urban and suburban community colleges offer more contract training than small rural colleges because small colleges lack the infrastructure and local demand for contract training (Lynch et al., 1991). Thus, according to the natural selection view, rural community colleges might be selected out of the business of providing contractual training services to corporate organizations as the natural drift of resources (e.g., technical resources, financial resources, demand for online contract training from corporate organizations) is against them. In such case, there might be a return to more focus on traditional academic and credit-bearing occupational courses. Since the natural selection view prescribes to a deterministic orientation as opposed to a voluntaristic one at the level of multiple 
organizations, groups of community colleges will tend to be in an inactive mode amidst challenges in the environment according to this view. However, some colleges take these same challenges and act in interactive ways. For example, some small rural colleges are making efforts to develop collaborative partnerships with industrial corporations (Warren, 2000). Warren (2000) provides a detailed example of such a rural community college in the Midwest hat has successfully collaborated with a local industrial organization for the purposes of providing customized contract training services. Such examples illustrate that irrespective of size and location, it is possible for community colleges to implement organizational changes to manipulate the natural drift of resources required for effective contract training when not existing in an inactive, deterministic manner.

\section{Interactive Role}

Lastly, the collective-action perspective contrasts the natural selection view by focusing on voluntaristic orientation at the level of multiple organizations. This perspective does not view organizations and institutions as products of environmental evolution; instead, it emphasizes collective survival, which is possible if different sectors and industries of organizations develop symbiotic collaborations with each other. Such collaborations will result in a regulated and controlled social environment that mediates the effects of the natural environment (Astley \& Van de Ven, 1983). The collective-action view is most relevant to explaining how many community colleges are trying to cope with the challenges of online contract training through organizational changes that have led to multiple collaborations with other institutions. Community colleges have increasingly forged formal and informal relationships with industrial corporations, universities, other community colleges across urban and rural locations, and competitors to create collective modules of online contract training programs. For example, the 15 community colleges in Iowa formed a partnership called the One Source Training, which provides a central 
source for Iowa businesses and organizations to purchase contract training (Saylor, 2006). The program offers all types of delivery, including online options. Many of the individual colleges in Iowa would likely have been unable to offer the wide variety of programs provided through One Source if they were not involved in this collaborative partnership. Such collaborations also allow for administrative cost sharing, creating efficiencies and freeing up money for other expenses.

Another example of such collective action among multiple community colleges, state, and corporate organizations would be the Michigan Virtual University (MVU) (Cappel \& Ahlbrand, 2002). A \$30 million investment from the Michigan Renaissance fund helped the Michigan Economic Development Corporation and several major industries in the state of Michigan to create MVU. The Michigan Virtual Automotive and Manufacturing College is a division of MVU that contracts with manufacturing companies to provide online noncredit contract training. These types of collaborations make it easier for both urban and rural community colleges across and within different states of the United States to overcome barriers of location, cut down on technology costs and to become effective providers of online contract training to industrial corporations. In another state, colleges across the state have niche areas and develop financial arrangements with each other to provide online and hybrid training with other colleges in the state (Githens, Wilson, Crawford, \& Sauer, 2009). Community colleges are also using such collaboration to train their faculty to use sophisticated technology in online pedagogy (Dougherty \& Bakia, 2000). Some community colleges have collaborated with the state government and industries as part of states' skills standards boards that monitor the quality of workforce education. The Texas Skill Standards Board (TSSB) is an example of such an organizational change that has resulted in collective quality control (Davis, 2008). Another possibility of forging collaborations that can help community colleges to manage the challenges 
of online contract training relates to President Obama's proposal for "open courses" in which modularized courses would be developed for free use by community colleges (Jaschik, 2009). Such an approach would allow for modularized courses to be shared by colleges. Instead of each institution paying to develop highly-specialized and interactive content such as online simulations and interactive activities, institutions would receive financial incentives from the federal government for developing highly successful content to be shared with other colleges. Thus, these examples of collective action and collaboration imply that there is significant potential for community colleges to implement organizational changes that leverage interorganizational networks to develop the resources and become more successful and efficient providers of online learning.

\section{Conclusions and Implications for HRD}

As online education continues to become more common and popular, a significant percentage of contract training will be delivered through online or hybrid formats, which will inevitably lead to broadening the reach of the workforce development arm of community colleges to include employers and organizations outside of their traditional service areas. This shift to online formats has the potential to increase relevance, reach, and accessibility of the workforce development arms of community colleges, while possibly complicating the mission of the individual institutions. As community colleges grapple with the ever-increasing expectation that they will play a central role in rebuilding the country's economy, tensions might continue growing as resources are diverted away from the traditional academic transfer programs.

In the current economic recovery efforts, President Obama has called on community colleges to be at the center of efforts to educate workers for high tech, high skill jobs (Obama, 2009; President's Council of Economic Advisers, 2009). In Obama's community college funding proposal, which would provide $\$ 12$ billion over 10 years, workforce development and online 
learning are two of the four priorities (Jaschik, 2009; Khadaroo, 2009). Thus, the demand for and opportunity to provide online training is growing and colleges will continue to seek creative organizational changes to efficiently offer such programs. A key component of the federal funding proposal is that funding be competitive and linked to innovations that result in significant outcomes. This paper recognizes this growing need and attempts to reconcile the multifaceted dimensions of the community mission by addressing concerns about the costs of providing online contract training through an organizational theory lens.

The paper has implications for HRD on several levels. First, the overlapping realms of workforce development and HRD are intertwined in many ways. This paper provides a conceptual understanding of contract training which is one form of HRD designed to benefit society, funded by both employers and government. Second, community colleges are major providers of online training, a significant form of HRD. The paper discusses this form of training within community colleges, which is understudied within HRD. Third and most importantly, the paper applies organization theory to shed light on what types of organizational changes community colleges can use to address some challenges of online contract training.. Application of Astley \& Van de Ven's (1983) rich framework provides a tool for use by leaders within community colleges. It helps to identify ways for community colleges to be proactive in forging collaborations for the purpose of providing effective online workforce development.

In particular, the strategic-choice and the collective-action views provide means of engaging in internal and external organizational change efforts in community colleges and thus, this paper recommends these two perspectives as preferable approaches that community colleges should prescribe to in order to address the barriers in providing online contract training. This application of a classical organizational theory framework provides an example of the power of using such tools when considering the implementation of organizational changes. Moving 
forward, future research can address this topic by collecting empirical data to address the ongoing tension between institutional mission, internal dynamics, and external pressures within institutions and groups of institutions. Such research will help to advance both theory and practice as community colleges continue to play an increasingly important role in our nation's workforce and economic development.

\section{References}

Allen, I. E., \& Seaman, J. (2003). Sizing the opportunity: The quality and extent of online education in the United States, 2002 and 2003. Retrieved from http://www.sloanc.org/resources/sizing_opportunity.pdf

Astley, W. G., \& Van de Ven, A. H. (1983). Central perspectives and debates in organization theory. Administrative Science Quarterly, 28, 245-273.

Bailey, T. \& Averianova, I. (1998). Multiple missions of community colleges: Conflicting or complementary? New York: Columbia University, Teachers College, Community College Research Center.

Bailey, T., Jacobs, J., \& Jenkins, D. (2004). Outsourcing of instruction at community college. Retrieved from http://www.stanford.edu/group/ncpi/unspecified/byauthor.htm

Boswell, K. (2000). Building Bridges or Barriers? Public policies that facilitate or impede linkages between community colleges and local school districts. New Directions for Community Colleges, 111, 3-15.

Bragg, D. D., \& Jacobs, J. (1993). Establishing an operational definition for customized training. Community College Review, 21(1), 15-25.

Cappel, J., \& Ahlbrand, J.(2002). A case study of web-based learning: The Michigan virtual university in training mode. AMCIS 2002 Proceedings Paper 107.

Cohen, A. M., \& Brawer, F. B. (1996). Policies and programs that affect transfer. Washington, 
DC: American Council on Education. (ED 385 336)

Cohen, A. M., \& Brawer, F. B. (2003). The American community college (4th ed.). San Francisco: Jossey-Bass.

Cox, R. D. (2005). Online education as institutional myth: Rituals and realities at community colleges. Teachers College Record, 107(8), 1754-1787.Davis, J. L. (2008) Community colleges: The preferred provider of career and technology education and training. Community College of Journal of Research and Practice, 32(8), 568-572.

Dougherty, K. J. (2003). The uneven distribution of employee training by community colleges: Description and explanation. Annals of the American Academy of Political and Social Sciences, 586(62), 62-91.

Dougherty, K., \& Bakia, M.(2000). Contract training and the community college: Origins and impacts. Teachers' College Review. Teachers College Press: New York.

Eaton, J. S. (1994). Strengthening collegiate education in community colleges. San Francisco: Jossey-Bass.

Foster, L. (2004). Meeting the Next Phase of Challenges.(2004). In B.L. Bower \& K.P. Hardy (Eds.). From Distance Education to E-Learning: Lessons Along the Way (New Directions for Community Colleges, (pp. 73-78). San Francisco: Jossey-Bass.

Githens, R. P., Wilson, K. B., Crawford, F., \& Sauer, T. (2009). [Interview from a multiple-case study project]. Unpublished raw data.

Grubb, W.N. \& Stern, D. (1989). Long time a'comin': Options for federal financing of postsecondary vocational education. Paper prepared for the U.S. Department of Education, National Assessment of Vocational Education, Washington, DC.

Instructional Technology Council (2008). 2007 distance education survey results: Tracking the impact of e-learning at community colleges. Available from 
http://4.79.18.250/file.php?file=/1/ITCAnnualSurveyMarch2008.pdf

Jacobs, J., \& Dougherty, K. J. (2006). The uncertain future of the community college workforce development mission. New Directions for Community Colleges, 136, 53-62.

Jaschik, S. (2009). The Obama plan [Electronic Version]. Inside Higher Ed. Retrieved from http:/www.insidehighered.com/news/2009/07/15/obama.

Jaschik, S. (2009). U.S. push for free online courses [Electronic Version]. Inside Higher Ed. Retrieved from http://www.insidehighered.com/news/2009/06/29/ccplan.

Katsinas, S. G. (1994). Is the open door closing? The democratizing role of the community college in the post-cold war era. Community College Journal, 64(5), 24-28.

Kasper, H. T. (2003). The changing role of community college. Occupational Outlook Quarterly, 46(4), 14-21.

Khadaroo, S. T. (2009). Obama directs $\$ 12$ billion to community colleges [Electronic Version]. Christian Science Monitor. Retrieved from http://features.csmonitor.com/politics/2009/07/14/obama-directs-12-billion-tocommunity-colleges/.

Levesque, K., Laird, J., Hensley, E., Choy, S. P., Cataldi, E. F., \& Hudson, L. (2008). Career and technical education in the United States: 1990 to 2005 (No. NCES 2008-035). Washington, DC: National Center for Education Statistics. Lynch, L., \& S.E. Black (1998). Beyond the incidence of employer-provided training. Industrial and Labor Relations Review, 52, 64 - 81.

Lynch, R., Palmer, J. C., \& Grubb, W. N. (1991). Community college involvement in contract training and other economic development activities. Berkeley: National Center for Research in Vocational Education, University of California at Berkeley. 
Moltz, D. (2009). Skills training à la carte [Electronic Version]. Inside Higher Ed. Retrieved from http://www.insidehighered.com/news/2009/08/12/kellogg.

Obama, B. (2009). Rebuilding something better [Electronic Version]. The Washington Post. Retrieved from http://www.washingtonpost.com/wpdyn/content/article/2009/07/11/AR2009071100647.html.

Orr, M. T. (2001). Community colleges and their communities: Collaboration for workforce development. New Directions for Community Colleges, 115, 39-49.

President's Council of Economic Advisers. (2009). Preparing the workers of today for the jobs of tomorrow. Washington, DC: Executive Office of the President.

Ruppert, S. S. (2001). Where we go from here: State legislative views on higher education in the new millennium Available from http://www2.nea.org/he/leg-news/images/gofrom.pdf

Saylor, C. (2006). One source training: Iowa community colleges leverage resources through statewide collaboration. Community College Journal of Research \& Practice, 30(2), 149150.

Van Noy, M., \& Jacobs, J. (2009). The outlook for noncredit workforce education. New Directions for Community Colleges, 146, 87-94.

Warren, J. (2000). Collaboration between a small rural community college and a large industrial corporation for customized training. Community College Journal of Research and Practice, 24(8), 667-679. 